Authors' submitted version of article published as:

Bruyère, S. \& Filiberto, D. (2013). The green economy and job creation: Inclusion of people

with disabilities. International Journal of Green Economics, 7(3), 257-275. doi: 10.1504/

IJGE . 2013.058151.

This is not the copy of record.

\title{
Title: The Green Economy and Job Creation: Inclusion of People with Disabilities
}

\author{
Susanne M. Bruyère, PhD, David M. Filiberto, PhD
}

\begin{abstract}
:
The percentage of total employment associated with green goods and services has increased in the United States over the past several years, presenting employment opportunities in a number of related emerging fields. As employment options arise to provide green goods and services, people with disabilities should have equitable employment opportunities in this growth sector of the American economy. A focused strategy to train and engage people with disabilities in the green economy can provide a talented and largely untapped segment of the U.S. workforce, a greater opportunity to participate in this growing employment sector than previously realized.
\end{abstract}

\section{Introduction}

Two relevant drivers converge to spur the current green economy in the United States - a desire to grow the economy with new technology after the great recession of 2009, and the mounting necessity to address the issues of a changing climate. Global efforts to mitigate the effects of climate change are underway, with mixed levels of support and success. The U.S. Congress enacted legislation in 2007 and 2009 that included significant funding to promote green jobs. As this economy grows in the United States alongside increased efforts to address climate change, people with disabilities are a segment of the workforce that ought to have equitable access to the emerging employment opportunities produced at the nexus of these efforts.

People with disabilities live throughout the United States (Figure 1), inhabiting both rural areas and once vibrant industrial and manufacturing locations. The demand for green jobs exists across the nation; from retrofitting buildings to make them more energy efficient, to production of renewable energy components for solar and wind development (Kopicki \& Cleary, 2009). People with disabilities can be powerful allies in the revitalization and economic development of their communities as the green jobs employment sector grows. 
Figure 1: Location and Prevalence of People with Disabilities in the United States (Source: Employment and Disability Institute, Cornell University)

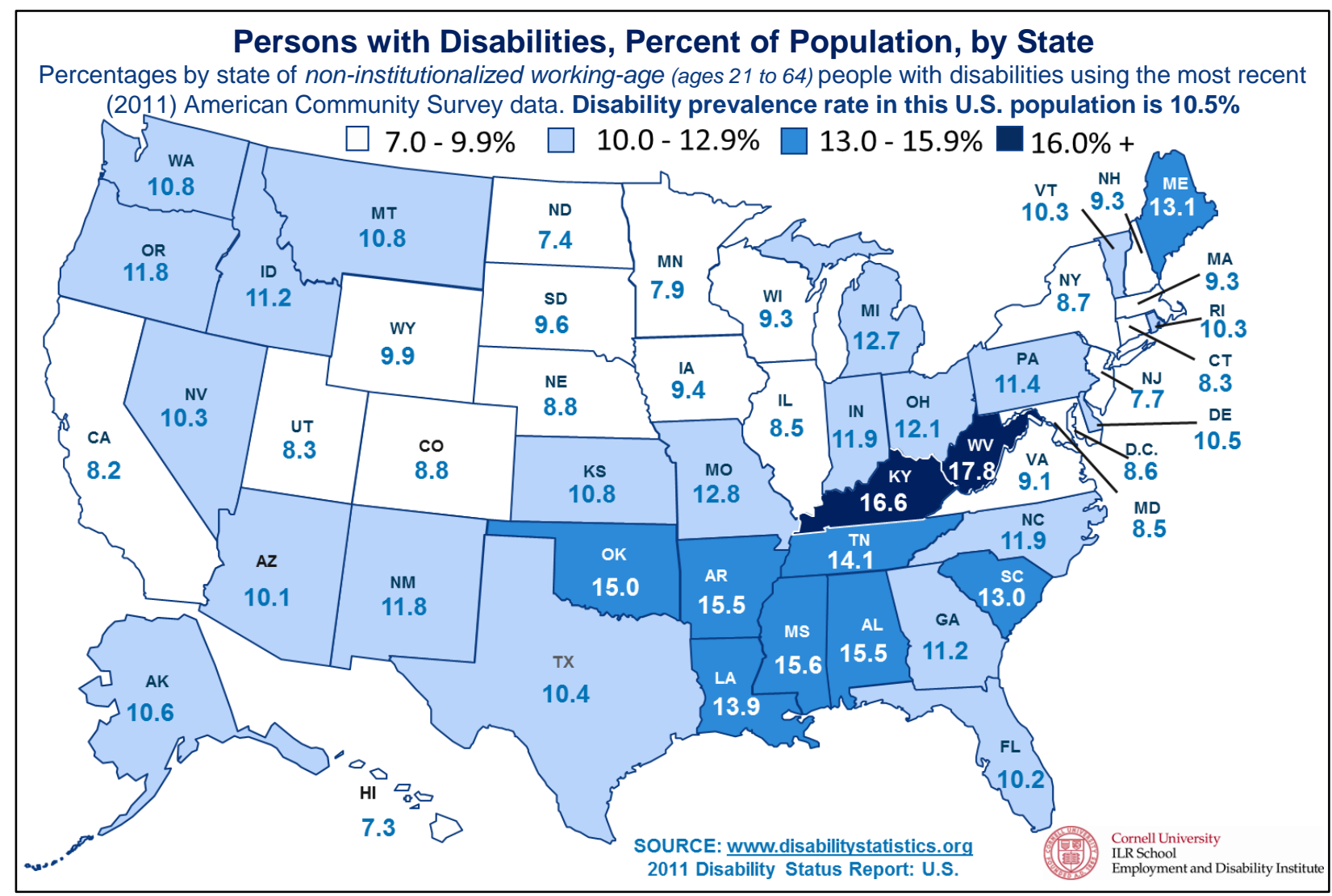

\section{The Green Employment Landscape}

A green jobs movement has been heralded by the media as a potential solution to lower unemployment and combat climate change (Fahey, 2009). However, in the absence of federal climate legislation and with political support for the stimulus of green jobs wavering, the potential role of a green economy is still developing. The U.S. Department of Labor's Bureau of Labor Statistics (BLS) has yet to provide a widely accepted standard classification and definition of "green jobs." Several studies reviewed by the BLS showed that neither the standard classification systems most frequently used (i.e., the North American Industry Classification System (NAICS), or the Standard Occupational Classification (SOC)) identifies green or environmental groups of industries or occupations (Sommers, Warren, \& Watson, 2013). Additionally, the BLS had to eliminate the tracking and reporting of green jobs due to the 2013 sequestration (BLS, 2013a). The tracking eliminated includes data on employment by industry and occupation for businesses that produce green goods and services; data on the occupations and wages of jobs related to green technologies and practices; and green career information publications.

In consideration of the above, the Bureau of Labor Statistics broadly defines green jobs as employment "in businesses that produce goods or provide services that benefit the environment or conserve natural resources" or "jobs in which workers' duties involve making their establishment's production processes more environmentally friendly or use fewer natural 
resources" (BLS, 2013b). However, the focus of this definition is on employment growth with less of an emphasis on job development. Therefore job quality is not highlighted. In addition, nuclear power and carbon capture and sequestration are sectors included in the definition, while the heath sector is excluded.

According to the BLS, potential green jobs include:

- Generation of energy from renewable sources (solar, wind, biofuels) including manufacturing, installation, and maintenance.

- Improving energy efficiency including services like home energy audits, home renovation and retrofitting, manufacture and provision of products like EE appliances, vehicles.

- Pollution reduction/removal, recycling, greenhouse gas reduction.

- Natural resource conservation including organic agriculture, sustainable forestry, storm water management.

- Environmental compliance, education and training including enforcing regulations, and public awareness.

A green job is then generally referred to as a variety of employment opportunities related to preserving or restoring the environment, reducing energy usage, or lowering carbon emissions. Usually these positions may be further divided into energy efficiency and renewable energy categories for the most prevalent opportunities in the green job space. Energy efficiency jobs can involve retrofitting homes or developing and manufacturing products that save energy. Renewable energy jobs include creating and maintaining technologies that generate energy from resources that are naturally replenished (i.e., solar and wind power).

\section{Legislative Action}

Green and sustainable job opportunities gained legislative support with passage of the Green Jobs Act of 2007 and the American Recovery and Reinvestment Act of 2009 (ARRA).

Title X of the Green Jobs Act authorized "up to \$125 million in funding to establish national and state job training programs, administered by the Department of Labor, to help address job shortages that are impairing growth in green industries, such as energy efficient buildings and construction, renewable electric power, energy efficient vehicles, and biofuels development" (Green Jobs Act, 2007). The bill was passed by Congress as part of the Energy Security and Independence Act of 2007, but was never funded.

As the economy entered the Great Recession, Congress intervened by passing ARRA in early 2009. ${ }^{1}$ This Act included provisions for new jobs in industries such as energy, utilities, construction, and manufacturing, with a focus toward energy efficiency and more environmentally friendly practices. In late 2009 and early 2010, the U.S. Department of Labor invested roughly $\$ 500$ million in green jobs grants under ARRA, releasing funds in four categories:

\footnotetext{
${ }^{1}$ Full text of the Act may be accessed here: http://www.gpo.gov/fdsys/pkg/BILLS-111hr1enr/pdf/BILLS$\underline{111 \mathrm{hr} l e n r . p d f}$
} 
- State Energy Sector Partnership and Training Grants (\$190 million),

- Pathways Out of Poverty Grants (POP) program (\$150 million),

- Energy Training Partnership Grants (\$100 million), and

- State Labor Market Information Improvement Grants and Green Capacity Building Grants (ARRA, 2009).

Two programs funded by ARRA, the Pathways out of Poverty (POP) Grants and the Energy Training Partnership Grants program, provide training for disadvantaged populations, including individuals with disabilities and displaced workers, to enter green occupations. The POP is a national workforce development program that targets individuals living below or near the poverty level to provide them with skills needed to enter the green job market, focusing on the energy efficiency and renewable energy industries (U.S. Department of Labor, 2010a). The Energy Training Partnership Grants provides training and placement services in the energy efficiency and renewable energy industries for workers impacted by national energy and environmental policy, individuals in need of updated training related to the energy efficiency and renewable energy industries, and unemployed workers (U.S. Department of Labor, 2010b) .

\section{Green Jobs in the U.S. Economy}

The growth of green jobs since 2006 is noteworthy. It was estimated in 2006 there were just a little more than 750,000 of what were then considered green jobs in the United States (Global Insight, 2008). Through 2007, green products and services comprised $1 \%$ to $2 \%$ of the total private sector economy with between 1.8 and 2.4 million jobs -- approximately a $180 \%$ increase (U.S. Department of Commerce, 2010). By 2010, 3.1 million jobs in the United States were associated with the production of green goods and services or $2.4 \%$ of total employment; by 2011, this number rose to 3.4 million jobs (BLS, 2012;BLS, 2013c).

The most recent BLS statistics from 2011 allocate more than 2.5 million green jobs to the private sector, while the public sector contained almost 900,000 jobs. The manufacturing sector of the private economy saw the greatest number of green jobs $(507,168)$ which include iron and steel production from recycled inputs, the production of air conditioning and refrigeration equipment meeting selected standards, hybrid cars and parts, and manufacture of pollution mitigation equipment (BLS, 2013c). 
Figure 2: Private sector employment in green goods and services, 2010-11 annual averages (Source: BLS, 2013c)

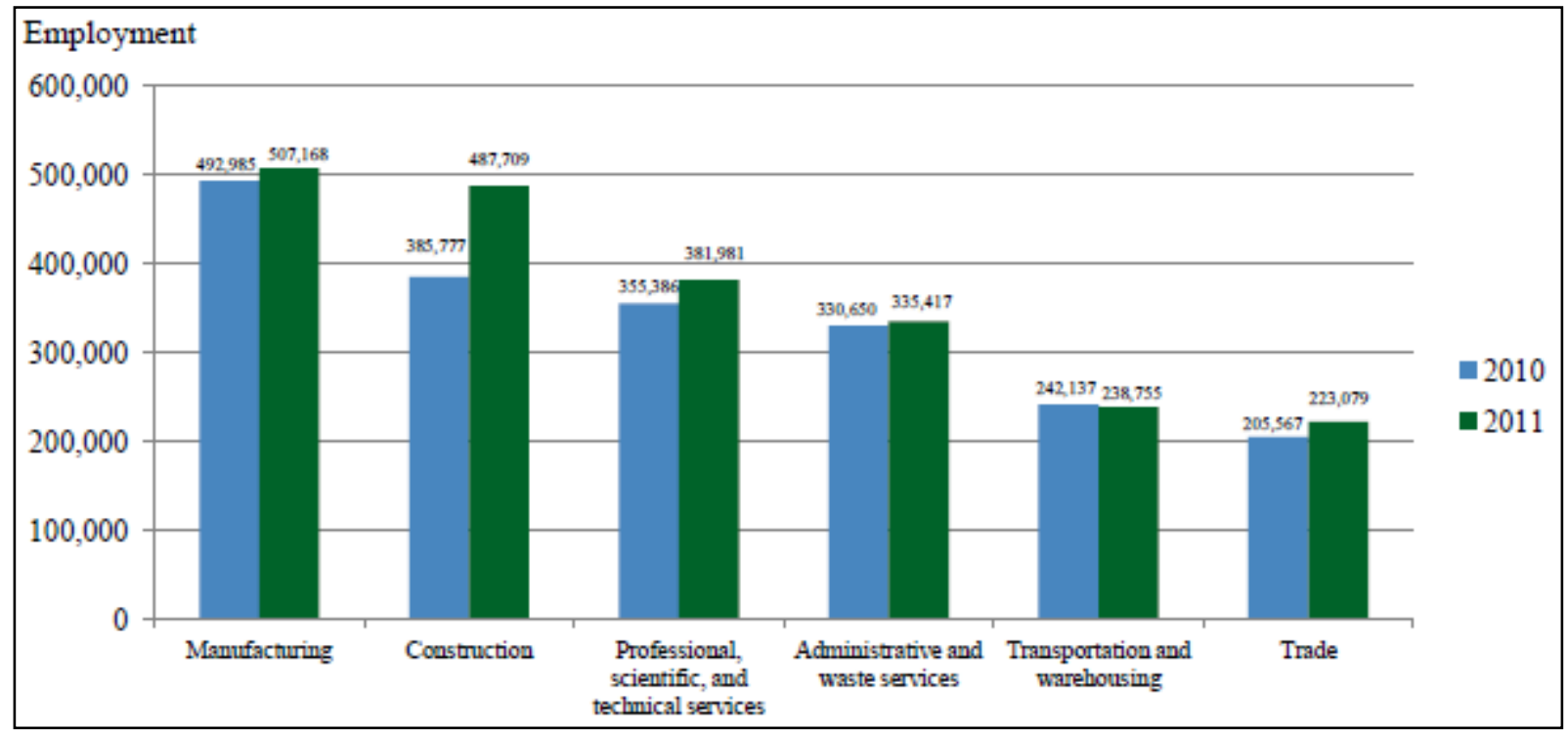

Despite the elimination of green jobs data collection by the BLS, it can be seen that the green jobs and goods and services sector of the economy is growing over time. Compared with the rest of the economy, green jobs grew at four times the rate of all the others combined (comparison with 2010 data) (Lee, 2013). If this trend continues, the potential exists for employment increasingly to be found in the production of green goods and services in industries such as renewable energy, pollution reduction and recycling, and natural resources conservation.

\section{Employment Climate for People with Disabilities}

It is important that policymakers include all members of society as they consider workforce development programs to support jobs in the growing green economy. Americans with disabilities have much to offer employers in this sector of the economy, and should be provided an equal chance to share in its full promise. Efforts to make these industries universally accessible to people with disabilities will not only benefit these individuals with employment and career advancement, but also their employers.

There exist approximately one billion people worldwide with a disability; this is $15 \%$ of the world's population. Globally, the employment rate for people with disabilities is significantly below that of the overall total population, ranging from $30-38 \%$ as opposed to $81-92 \%$ for those without disabilities (Bruyère, S., Mitra, S., \& VanLooy, 2011). In the United States approximately 37 million people, or $12 \%$ of the population, report one or more disabilities (Erickson, Lee, \& von Schrader, 2012). The employment rate for working age people with a disability is only $33 \%$ with median annual earnings of $\$ 36,700$. Furthermore, the prevalence of disability rises with age; nearly $75 \%$ aged 65 and older report a disability.

One reason many of those with a disability are unemployed is employer's misconceptions about the capabilities of people with disabilities. Research has shown there is a belief that individuals with disabilities are less productive in the workplace and that different impairments elicit 
different degrees of prejudice (e.g. prejudice about mental health conditions) (Bruyère, Mitra, and VanLooy, 2011). This results in rather low expectations of people with disabilities by many employers, an unfounded misconception.

Employees with disabilities experience a host of difficulties and hardships once on the job. Many people with disabilities have reported they are placed in positions where there is "less of a fit" between their skills and demands of the job. They report less empowerment on the job, perceived lack of organizational support, lower quality relationships with their managers, and the perceptions their work arrangements are less fair (especially fairness of job responsibilities \& access to mentors) (Nishii, L. \& Bruyere, 2009).

When an employee decides to inform an employer about a disability, it is very important that the employee mention a need for specific accommodations, that a supportive supervisory relationship in place, and that the employer has encouraged a disability friendly workforce. The focus should be on creating an environment that encourages disclosure. Workplace managers and personnel should aim to create an environment of inclusion, avoiding focusing on disability or treating people with disabilities differently than the larger pool of employees (Schrader \& Malzer, 2011). Without these components, people with disabilities face the unnecessary hardship of competing in the employee marketplace on an even level.

A number of issues continue to impact the labor market for people with disabilities including productivity differentials, imperfections related to discrimination and prejudice, and disincentives created by disability benefit systems (Bruyère, S., Mitra, S., \& VanLooy, 2011). To address these issues, many countries have laws prohibiting discrimination on the basis of disability, making it illegal to make decisions about a person's employment on the basis of their disability. Enforcement of these laws is expected to improve access to the formal economy.

In the U.S. there are many incentives aimed to increase employment opportunities for people with disabilities. The most frequently used employer incentives for hiring individuals with disabilities are the Work Opportunity Tax Credit, the Welfare-to-Work Tax Credit, and the Veterans Job Training Act (Lengnick-Hall, Gaunt, \& Collison, 2003). Additionally, vocational rehabilitation and employment services (job training, counseling, job search assistance, and placement) can expand the capabilities of people with disabilities to compete and gain inclusion in the labor market (Bruyère, S., Mitra, S., \& VanLooy, 2011).

In addition to taking advantage of these incentives, employers can independently create a supportive and inclusive environment by undertaking the following:

- Develop partnerships with local employment agencies, schools, training programs, social programs;

- Actively recruit and hire people with disabilities;

- Make accommodations, when needed;

- Establish disability management programs to support return to work after the onset of a disability or serious health condition;

- Provide training that ensures that all supervisors and human resource staff are familiar with legal requirements regarding accommodation and nondiscrimination, 
- Commit to be a model employer and contribute to the establishment of supportive employer networks locally, nationally and globally (Bruyère, 2012).

Individuals with disabilities who work in an inclusive climate report significantly greater success at having their accommodation requests granted, improved coworker support of these accommodations, lower levels of disability related harassment, and lower turnover, leading to productive and fulfilling experience for both employee and employer (Nishii, L. \& Bruyere, 2009).

\section{The Business Case for Hiring Individuals with Disabilities}

There is mounting evidence that hiring people with disabilities while proactively creating an environment for disability inclusiveness is good for business (U.S. Department of Labor - ODEP, 2013). The addition of workers with disabilities often offers a competitive edge. By incorporating people with disabilities into human resource strategies, employers expand their pool of talent, skills, and creative business solutions. The Office of Disability Employment Policy (ODEP) of the U.S. Department of Labor asserts that businesses who hire people with disabilities potentially have a greater return on investment. New markets are accessed when people with disabilities are employed, and the costs which can be associated with conflict and litigation are as a result reduced. Consequently, customers with disabilities and their associates represent the third largest market segment in the U.S., approximating a trillion dollar market(U.S. Department of Labor - ODEP, 2013). The research shows that consumers both with and without disabilities favor businesses that employ people with disabilities.

When people with disabilities participate in the labor market, not only is the greater pool of human resources maximized leading to improved return on investment, but employers are promoting human dignity and social cohesion. The World Report on Disability (2011) finds accommodating the increasing numbers of people with disabilities in the working age population will become more necessary as a greater percentage of the population ages.

Disability advocates should attempt to ensure that any new workforce development projects include workers and potential workers with disabilities. Not only are these investments good for a business' bottom line, but people with disabilities can become great allies and partners in emerging economies such as in the green, digital age, and other innovative industries.

\section{Intersection of Disability and Sustainability}

A Green Jobs movement is bolstered by the concept that conservation and positive environmental outcomes can occur concurrently with economic development. Creating jobs through energy efficiency, production of green goods, and investments in behaviors that improve the environment can simultaneously generate a positive return on investment. Rewarding green businesses and industries that incorporate best practices in recruiting, hiring, accommodating, retaining, and promoting employees with disabilities in their business models is a recommended strategy.

There are few limitations to the type of jobs available to people with disabilities in the green economy. Jobs in existing manufacturing sectors undergoing a transformation to more sustainable industries via changes in efficiency (i.e., energy, resource, waste and water efficiencies) are some of the most prevalent (BLS, 2013c). Jobs manufacturing green goods such 
as solar panels, wind turbines, and recycled products are also included in this vast category. Jobs enabled through sustainable manufacturing (collection centers, materials recovery, recycling, efficient transportation) are additionally considered large green employers (US Department of Labor - ODEP NTAR Leadership Center, 2011a).

Of the 22 major occupational groups, all have persons with disabilities employed in them (Table 1). Even at the most detailed level (nearly 500 occupations), all but two occupations had at least a few persons with a disability (Erickson, 2013). 
Table 1: Occupation Distribution by Disability Status (ACS 2011)

\begin{tabular}{|c|c|c|}
\hline \multirow[t]{2}{*}{ Occupational group } & \multicolumn{2}{|c|}{ Disability status } \\
\hline & No disability & Disability \\
\hline Management Occupations & $10.1 \%$ & $7.1 \%$ \\
\hline Business \& Financial Operations Occupations & $5.0 \%$ & $3.4 \%$ \\
\hline Computer \& Mathematical Occupations & $2.8 \%$ & $1.6 \%$ \\
\hline Architecture \& Engineering Occupations & $1.9 \%$ & $1.2 \%$ \\
\hline Life, Physical, \& Social Science Occupations & $0.9 \%$ & $0.5 \%$ \\
\hline Community \& Social Services Occupations & $1.7 \%$ & $1.8 \%$ \\
\hline Legal Occupations & $1.2 \%$ & $0.8 \%$ \\
\hline Education, Training, \& Library Occupations & $6.3 \%$ & $4.8 \%$ \\
\hline Arts, Design, Entertainment, Sports, \& Media Occupations & $1.9 \%$ & $1.5 \%$ \\
\hline Healthcare Practitioners \& Technical Occupations & $6.0 \%$ & $4.0 \%$ \\
\hline Healthcare Support Occupations & $2.6 \%$ & $3.0 \%$ \\
\hline Protective Service Occupations & $2.3 \%$ & $2.2 \%$ \\
\hline Food Preparation \& Serving Related Occupations & $4.8 \%$ & $5.8 \%$ \\
\hline Building \& Grounds Cleaning \& Maintenance Occupations & $3.9 \%$ & $6.6 \%$ \\
\hline Personal Care \& Service Occupations & $3.3 \%$ & $4.2 \%$ \\
\hline Sales \& Related Occupations & $10.1 \%$ & $9.5 \%$ \\
\hline Office \& Administrative Support Occupations & $13.5 \%$ & $14.5 \%$ \\
\hline Farming, Fishing, \& Forestry Occupations & $0.7 \%$ & $0.9 \%$ \\
\hline Construction \& Extraction Occupations & $5.2 \%$ & $5.2 \%$ \\
\hline Installation, Maintenance, \& Repair Occupations & $3.5 \%$ & $4.1 \%$ \\
\hline Production Occupations & $6.1 \%$ & $8.5 \%$ \\
\hline Transportation \& Material Moving Occupations & $5.9 \%$ & $8.5 \%$ \\
\hline Military Specific Occupations & $0.4 \%$ & $0.3 \%$ \\
\hline Total & $100.0 \%$ & $100.0 \%$ \\
\hline
\end{tabular}


The U.S. Bureau of Labor Statistics provides a very broad definition of green jobs, one that provides infinite potential for including people with disabilities,

Green jobs are jobs in businesses that produce goods and provide services that benefit the environment or conserve natural resources

These include varied positions in natural resources and mining activities, transportation and warehousing, to financial activities among others (see Table 2 below). Of the 3.4 million green jobs counted in 2011 , nearly $72 \%$ exist in private industry.

Table 2: Green Goods and Services Employment by Industry Sector, 2010 - 2011 (Source: BLS, 2013d)

\begin{tabular}{|c|c|c|c|c|c|c|}
\hline \multirow{2}{*}{ Industry } & \multirow{2}{*}{$\mathrm{NAICS}^{1}$} & \multicolumn{2}{|c|}{ GGS employment $^{2}$} & \multicolumn{2}{|c|}{ GGS percent $^{3}$} & \multirow{2}{*}{$\begin{array}{c}\text { GGS } \\
\text { employment } \\
\text { change from } \\
2010-2011\end{array}$} \\
\hline & & 2010 & 2011 & 2010 & 2011 & \\
\hline Total, all industries.......... & & $3,243,533$ & $3,401,279$ & 2.5 & 2.6 & 157,746 \\
\hline Total private................. & & $2,342,562$ & $2,515,200$ & 2.2 & 2.3 & 172,638 \\
\hline Natural resources and mining. & 11,21 & 63,344 & 64,689 & 3.5 & 3.4 & 1,345 \\
\hline Utilities. . . . . . . . . . . . . . . . . & 22 & 69,031 & 71,129 & 12.5 & 12.9 & 2,098 \\
\hline Construction. ............. & 23 & 385,777 & 487,709 & 7.0 & 8.9 & 101,932 \\
\hline Manufacturing...... & $31-33$ & 492,985 & 507,168 & 4.3 & 4.3 & 14,183 \\
\hline 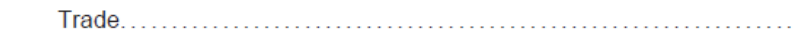 & $42,44-45$ & 205,567 & 223,079 & 1.0 & 1.1 & 17,512 \\
\hline Transportation and warehousing. . & $48-49$ & 242,137 & 238,755 & 6.1 & 5.9 & $-3,382$ \\
\hline Information. .................... & 51 & 33,321 & 29,412 & 1.2 & 1.1 & $-3,909$ \\
\hline Financial activities. .................................... & 52,53 & 462 & 475 & 0.0 & 0.0 & 13 \\
\hline Professional, scientific, and technical services..................... & 54 & 355,386 & 381,981 & 4.8 & 5.0 & 26,595 \\
\hline Management of companies and enterprises ......................... & 55 & 62,630 & 69,310 & 3.4 & 3.6 & 6,680 \\
\hline 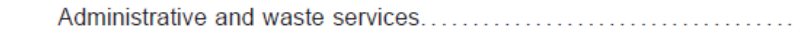 & 56 & 330,650 & 335,417 & 4.5 & 4.3 & 4,767 \\
\hline Education and health services. ............................... & 61,62 & 28,789 & 26,123 & 0.2 & 0.1 & $-2,666$ \\
\hline Leisure and hospitality......................... & 71,72 & 20,642 & 23,696 & 0.2 & 0.2 & 3,054 \\
\hline Other services, except public administration. . & 81 & 51,841 & 56,257 & 1.2 & 1.3 & 4,416 \\
\hline Federal government. ..................... & & 208,744 & 213,340 & 7.0 & 7.5 & 4,596 \\
\hline State government..... & & 256,224 & 248,539 & 5.6 & 5.5 & $-7,685$ \\
\hline Local government. .................. & & 436,002 & 424,201 & 3.1 & 3.1 & $-11,801$ \\
\hline
\end{tabular}

Occupational titles of several positions that provide the green goods and services above are listed below (Table 3). Although these positions represent a sample of some of the more common opportunities in the sector, skills and expertise gained are potentially transferrable to other suitable roles within and outside of the green sector as the green economy continues to grow. It can be seen that many green careers represent traditional construction, manufacturing, engineering, and managerial roles. 
Table 3: Green Careers Fields and Typical Occupations

\begin{tabular}{|c|c|c|c|c|c|}
\hline $\begin{array}{l}\text { Energy Efficiency - } \\
\text { Residential } \\
\text { Weatherization }\end{array}$ & $\begin{array}{l}\text { Commercial and } \\
\text { Industrial Retrofits }\end{array}$ & Solar Power & Wind Power & Bioenergy & Recycling \\
\hline Electricians & $\begin{array}{l}\text { Building } \\
\text { Weatherization Project } \\
\text { Managers }\end{array}$ & $\begin{array}{l}\text { Solar } \\
\text { Photovoltaic } \\
\text { Installers }\end{array}$ & $\begin{array}{l}\text { Environmental, } \\
\text { Energy } \\
\text { Engineers }\end{array}$ & $\begin{array}{l}\text { Biochemists, } \\
\text { Soil Scientists, } \\
\text { Laboratory } \\
\text { Technicians }\end{array}$ & Drivers \\
\hline $\begin{array}{l}\text { Heating/Air } \\
\text { Conditioning Installers }\end{array}$ & Electrical Engineers & $\begin{array}{l}\text { Computer- } \\
\text { Controlled } \\
\text { Machine Tool } \\
\text { Operators }\end{array}$ & $\begin{array}{l}\text { Iron and Steel } \\
\text { Workers }\end{array}$ & $\begin{array}{l}\text { Environmental } \\
\text { Engineers }\end{array}$ & Sorters \\
\hline $\begin{array}{l}\text { Carpenters, Carpenter } \\
\text { Helpers }\end{array}$ & Mechanical Engineers & $\begin{array}{l}\text { Welding, } \\
\text { Soldering, and } \\
\text { Brazing } \\
\text { Workers }\end{array}$ & $\begin{array}{l}\text { Sheet Metal } \\
\text { Workers }\end{array}$ & $\begin{array}{l}\text { Construction } \\
\text { Laborers }\end{array}$ & $\begin{array}{l}\text { Mechanics, } \\
\text { Technicians, } \\
\text { and Machinery } \\
\text { Maintenance } \\
\text { Workers }\end{array}$ \\
\hline $\begin{array}{l}\text { Construction Equipment } \\
\text { Operators }\end{array}$ & $\begin{array}{l}\text { Cogeneration } \\
\text { Construction and } \\
\text { Operation }\end{array}$ & $\begin{array}{l}\text { Semiconductor } \\
\text { Processors }\end{array}$ & $\begin{array}{l}\text { Machinists, } \\
\text { Millwrights }\end{array}$ & $\begin{array}{l}\text { Farmers and } \\
\text { other } \\
\text { Agricultural } \\
\text { Managers }\end{array}$ & $\begin{array}{l}\text { Material } \\
\text { Recovery } \\
\text { Facility } \\
\text { Managers }\end{array}$ \\
\hline Roofers & $\begin{array}{l}\text { Measurement and } \\
\text { Verification } \\
\text { Technicians }\end{array}$ & $\begin{array}{l}\text { Coating and } \\
\text { Painting } \\
\text { Machine Setters, } \\
\text { Operators, and } \\
\text { Tenders }\end{array}$ & $\begin{array}{l}\text { Electrical } \\
\text { Equipment } \\
\text { Assemblers }\end{array}$ & $\begin{array}{l}\text { Plant managers } \\
\text { and Operators }\end{array}$ & Route Managers \\
\hline Insulation Workers & $\begin{array}{l}\text { Energy Management } \\
\text { Analysts }\end{array}$ & $\begin{array}{l}\text { Electrical and } \\
\text { Electronics } \\
\text { Installers and } \\
\text { Repairers }\end{array}$ & $\begin{array}{l}\text { Construction } \\
\text { Equipment } \\
\text { Operators }\end{array}$ & $\begin{array}{l}\text { Purchasing } \\
\text { Agents }\end{array}$ & \\
\hline \multirow[t]{5}{*}{ Energy Auditors } & & $\begin{array}{l}\text { Electrical and } \\
\text { Electronic } \\
\text { Equipment } \\
\text { Assemblers }\end{array}$ & $\begin{array}{l}\text { Industrial Truck } \\
\text { Drivers }\end{array}$ & $\begin{array}{l}\text { Chemical } \\
\text { Equipment } \\
\text { Operators and } \\
\text { Tenders }\end{array}$ & \\
\hline & & $\begin{array}{l}\text { Industrial } \\
\text { Production } \\
\text { Managers }\end{array}$ & $\begin{array}{l}\text { Industrial } \\
\text { Production } \\
\text { Managers }\end{array}$ & $\begin{array}{l}\text { Industrial } \\
\text { Machinery } \\
\text { Mechanics }\end{array}$ & \\
\hline & & $\begin{array}{l}\text { Construction } \\
\text { Managers }\end{array}$ & $\begin{array}{l}\text { Operators, } \\
\text { Maintenance } \\
\text { Technicians }\end{array}$ & & \\
\hline & & Civil Engineers & & & \\
\hline & & $\begin{array}{l}\text { Structural Iron } \\
\text { and Steel } \\
\text { Workers }\end{array}$ & & & \\
\hline
\end{tabular}

Despite the existence of a variety of occupations for people with disabilities to enter into the green economy, targeting such positions can introduce future longer-term employment disparities that need to be carefully considered .Green jobs are often entry-level, and advancement without further training is improbable. Liu and Keleher's (2009) assessment illustrates that current green workforce job training exists independent of the occupational demand in the field. Graduates of these programs often find the job they just trained for exists in 
a thin and tight labor market. They also demonstrate that current green organizations are not employing traditionally underrepresented groups at higher rates than non-green firms.

Given these considerations, Bird, Lawton, \& Purnell (2010) provide four key principles for creating what they term a 'decent' green job:

- Keep it local: National policy decisions should be informed by local knowledge and action. Local level knowledge is required to understand which kinds of green jobs are viable in the service area, what barriers exist, and aim to identify which local organizations might be able to help.

- Cross sectional partnerships: Coalitions of training and community networks have been most effective at creating quality green jobs.

- Not just jobs: Including objectives such as poverty reduction and workplace safety from the beginning is vital.

- Link job training with job creation: Jobs must be available to apply new skills. It is very important to unite job creation opportunities and workforce development programs with the appropriate demand for green goods and services, ensuring a viable connection between unemployment and green work.

\section{Implementing a Green Jobs Program for Individuals with Disabilities}

Individuals with disabilities can fill many of the proposed green jobs, provided they receive the necessary training and support. Since people with disabilities are already underrepresented in the workforce, they should be prioritized as a target group to receive training and support to pursue high skilled careers in green and other high demand fields. The National Council for Workforce Education and the Academy for Educational Development's report, Going Green (Feldbaum \& States, 2009) demonstrates the vital role of workforce education in building a green labor force. Workforce development programs partnered with community colleges is one collaborative model to prepare workers for new green jobs. As people with disabilities enter the growing green sector of the economy, policy makers and employers should continue to promote and support necessary public and private collaborations and investments aimed at increasing the participation of this talented segment of the workforce.

An effort to provide a policy framework for including people with disabilities in the green workforce occurred in 2009. The National Technical Assistance and Research (NTAR) Leadership Center in partnership with the Office of Disability Employment Policy (ODEP) sponsored a symposium titled Strategies for Including People with disabilities in the Green Jobs Talent Pipeline. The resulting roundtable discussion of thought leaders in the disability field developed several key policy recommendations to assist and incentivize public and private sector actors in promoting the greater inclusion of people with disabilities in the green economy (U.S. Department of Labor - ODEP NTAR Leadership Center, 2011b). These include,

- Federal and state green job training grants and contracts should encourage the use of universal design principles to better serve all clients. ${ }^{2}$

\footnotetext{
${ }^{2}$ Universal design refers to the use of common strategies that benefit many groups as opposed to few, and that reinforce the concept of an inclusive setting welcoming and celebrating diversity. Its key principles are simplicity, flexibility and efficiency.
} 
- People with disabilities should be explicitly referenced in national green job promotion efforts.

- Practices that have been documented to improve employment for people with disabilities should be encouraged for national green job funding.

- Federal programs and resources need to reinforce and foster collaboration across service agencies, levels of government, and programs to reduce duplication of efforts.

- The federal government should support the mapping of newly available green jobsrelated resources and training opportunities at the federal, state, and local levels.

- Federal, state, and local governments and service providers need help marketing green jobs opportunities to people with disabilities.

- Encourage greater use of current federal and state tax incentive programs, as well as create incentives for hiring people with disabilities into the green jobs sector in concert with strong training and job creation strategies.

- Develop green job career pathways and ladders as well as performance measures for federal employment and training programs that reward job retention and career advancement instead of short-term placement goals

Although many of these recommendations reference a federal top-down approach to green job creation, it should not go unnoticed that perhaps these suggestions are most relevant for the state and local municipal workforce development organizations to consider.

\section{Including People with Disabilities}

As noted, it is important for workforce investments to incorporate the concept of universal access and universal design as an essential part of green employment and economic development efforts. Universal strategies increase the ease of access to products, places, and services for multiple, diverse populations - in this case a focus on green job creation for people with disabilities. Scully-Russ (2012) further suggests implementing a career pathways model, which links education and training with work experience and credentialing to provide work-based stepping stones to meet labor market demand. Public workforce development programs and industry stakeholders coordinate to make the training a worker pursues labor market demand driven.

There therefore exist several routes for people with disabilities to enter the green workforce, as outlined by ODEP. This federal agency recommends that workforce development professionals and employers access a mix of public, private, and non-profit resources to recruit people with disabilities into the green workforce (U.S. Department of Labor - ODEP, 2013):

1. Public recruiting sources, including One-Stop Career Centers established under the Workforce Investment Act.

2. Educational institutions, including community colleges, universities, and other institutions of learning and/or training, including those that offer programs for individuals with specific disabilities, such as persons who are blind, deaf, and have learning disabilities.

3. Non-profit entities and social service agencies, including labor organizations, organizations for individuals with disabilities, and other entities that may provide referrals, technical assistance, and other advice on proper placement, recruitment, and accommodations. 
4. Private recruiting sources, including professional organizations, consulting services, and companies with expertise in disability.

Furthermore, recent disability research provides evidenced based approaches to increase recruitment and hiring of people with disabilities (SHRM - Cornell, 2012). These include introducing disability into diversity initiatives, providing disability awareness training for recruiters, proactive recruitment form institutions of higher education, and establishing the important relationships with local community employment service providers. These findings reiterate the importance of workforce development efforts focused at the local level, establishing the necessary relationships to enact measurable results.

The Society for Human Resource Management (SHRM) and Cornell study (2012) also provides recommended approaches to increase retention and advancement of people with disabilities in the green workforce. The following activities are found to provide a rewarding, inclusive environment promoting retention and advancement:

- Regular and consistent performance management

- Regular re-evaluation of accommodations

- Effective disability case management

- Accessible career opportunities information

- Professional development and training

- Formal and informal mentoring

- Special assignments and project work

- Facilitating group/team project opportunities

- Metrics on retention and advancement

These strategies and recommendations provide a foundation for workforce development professionals to assist people with disabilities in the green economy. Of equal importance is the supporting role public and private actors take in creating a coordinated effort to include people with disabilities in the green movement.

\section{Role of Government}

The federal government has promoted the development of a green economy, passing of ARRA and putting in place nearly $\$ 500$ million in resources for the states and municipalities to utilize. The Department of Labor oversaw the majority of this funding, investing in skills development for individuals to participate in the emerging green economy. Independent assessments found that ARRA's green jobs and clean energy incentives were effective in providing workers with green skills training and leveraging private sector investment (Aldy, 2012; Government Accountability Office, 2013). These positive outcomes occurred despite the wavering aggregate demand for green jobs and clean energy, in an environment where the business sector undertook a dramatic deleveraging during the financial crisis. Government investment through grants and tax credits assisted the increase in economic activity, while improving the quality of the projects by engaging both public and private sector actors.

Despite misgivings concerning public expenditures toward the outcome of a less than fully developed green economy (Office of Inspector General - Office of Audit, 2011; Morriss, Bogart, Dorchak, \& Meiners, 2009), public benefits accrued. The largest gap between the proposed outcome and post evaluation was the lack of demand for placing newly trained workers with 
green employers. As public workforce investments move forward, finding solutions to this labor market imbalance should be a high priority.

The federal government's role in continuing to promote a green economy requires a fairly major policy shift, involving a much bigger role for the public sector. Past policy has attempted to grow the green economy through incentives for investments, creating "enabling environments" for private business. Placing the responsibility to lead the drive for a green economy solely on the private sector has had mixed results. In the future, cooperative pilots by states and municipalities synced with the needs of private employers, non-profits, and educational institutions can test effective ways of supporting people with significant disabilities who are on SSDI or SSI. A crucial role is played by the partnership among public and private actors including local networks, particularly trade unions.

As the economy continues to move toward increasing sustainability, the availability of green jobs and the demand for new skills should increase. Federal legislation aimed at reducing greenhouse gas emissions, new investments for research and development of efficient and renewable energy, green universal design, hybrid cars, public transit, and affordable housing, all can drive employment opportunities for Americans, including those with disabilities and their families.

The National Council for Advanced Manufacturing (2008) recommends national standards for training for new skills in emerging technologies and sustainable manufacturing. Ideally, these positions will involve public and private partnerships high schools, community colleges, and technical schools to prepare the sustainable jobs workforce.

\section{Role of Entrepreneurship}

In much of the world people with disabilities primarily work in the informal economy. Selfemployment has been promoted as one option to respond to employment rate disparities. Selfemployment presents options for personalized accommodations not easily found in wage employment. However, self-employment should not serve as a substitute for overall proper job development (Bruyère, Mitra, and VanLooy, 2011).

Encouraging and funding green small businesses owned and controlled by entrepreneurs with disabilities can provide underlying infrastructure support for green industries. Many green jobs are in fact local jobs with an emphasis on community and local responsibility (e.g. improving energy efficiency). Workforce development support for entrepreneurs should address concerns about local job losses and growth of the community workforce. However, the issue of sustainability encourages a larger discussion on what in fact "growth" is - whether or not the investment meets the standards of a green job. Does the economic development activity aimed at including people with disabilities in the growing local economy remain sustainable? It is a question worth asking.

\section{Role for Non-Profits and Grass Roots Advocacy Organizations}

Non-profit economic development and grassroots advocacy groups can assist in closing the gap between green skills training for people with disabilities and the demand for green jobs. Since these organizations are often closely linked with the needs of local workforce and business community, they can work with employers to provide targeted support when mainstream opportunities are unavailable. The establishment of community coalitions of workforce and economic development interests, private enterprise, and not for profit organizations serving the 
employment preparation needs of individuals with disabilities is an important part of moving us globally along the continuum to longer term success in employment of people with disabilities globally.

\section{Conclusion}

A purpose of many workforce development programs for people with disabilities is aimed at addressing workplace barriers and changing attitudes from exclusion to inclusion of people with disabilities on the job. The presence of disability in workplace itself can change attitudes in that workplace. The outcome of a changed employer attitude toward disability potentially improves chances of promotion and advancement for people with disabilities.

As the green economy grows, many people with disabilities will and ought to be seeking employment in this sector of the economy. The review of green jobs created from the stimulus package illustrates that many are traditional jobs like construction, engineering, and mechanicskilled employment requiring a layer of green knowledge and training. Continued public spending on the development of the green economy is likely in the short-term future. It will be important for job counselors and job seekers, including those with and without disabilities, to have available better information on the connections between training and job availability to make informed choices.

The primary finding of this paper is that benefits accrue to employers and people with disabilities by introducing disability considerations into mainstream public policy. The following broad recommendations for state and local workforce development professionals as they seek to support green job training programs are:

- Apply rigorous standards for funding green industry training providers;

- Establish and make available a thorough inventory and clearinghouse of existing training programs in the green jobs area to address gaps;

- Develop and support high quality partnerships with green industry employers that include hiring agreements and access to career advancement; and

- Construct tools and training manuals that provide program funders, counselors, and people with disabilities job seekers better information on labor market demand in the emerging green industry as it evolves, with opportunities for continuous feedback.

People with disabilities remain a talented segment of the workforce, capable of undertaking most forms of appropriate employment. As the green economy grows, education and training opportunities should be focused and tailored to people with disabilities. 


\section{References}

Aldy, J. E. (2012). A Preliminary Review of the American Recovery and Reinvestment Act's Clean Energy Package. Retrieved from http://www.rff.org/Publications/Pages/PublicationDetails.aspx?PublicationID=21725

ARRA. (2009). American Recovery and Reinvestment Act of 2009 (2009; 111th Congress H.R. 1) - GovTrack.us. Retrieved August 07, 2013, from http://www.govtrack.us/congress/bills/111/hr1

Bird, J., Lawton, K., \& Purnell, K. (2010). Green and Decent Jobs. Retrieved from http://www.gulbenkian.org.uk/pdffiles/ippr-Green-and-decent-jobs.pdf

BLS. (2012). Employment in Green Goods and Services - 2010. Retrieved from http://www.bls.gov/news.release/archives/ggqcew_03222012.pdf

BLS. (2013a). Green Goods and Services Summary. Green Goods and Services Summary. Retrieved August 08, 2013, from http://www.bls.gov/news.release/ggqcew.nr0.htm

BLS. (2013b). BLS Green Jobs Definition. US Department of Labor. Retrieved from http://www.bls.gov/green/

BLS. (2013c). Employment in Green Goods and Services - 2011. Retrieved from http://www.bls.gov/news.release/pdf/ggqcew.pdf

BLS. (2013d). Green Goods and Services (GGS). Retrieved August 16, 2013, from http://www.bls.gov/ggs/ggsoverview.htm\#definition

Bruyère, S. M. (2012). Sustainability \& Job Creation: Inclusion of People with Disabilities. In Conferencia SUDI 2012 Sustainability and Disability Manaus, Brazil.

Bruyère, S., Mitra, S., \& VanLooy, S. (2011). World Report on Disability, Chapter 8 : Work and Employment. In Geneva: World Health Organization.

Erickson, W. A. (2013). Occupation distribution by disability status (ACS 2011). Personal communication.

Erickson, W., Lee, C., \& Schrader, S. von. (2012). 2011 Disability Status Reports: United States. Retrieved from http://digitalcommons.ilr.cornell.edu/edicollect/1285/

Fahey, A. (2009). Sightline Memorandum : Green Jobs Messaging Guide. Retrieved from http://daily.sightline.org/files/downloads/2012/04/gcj_memo_final.pdf

Feldbaum, M., \& States, H. (2009). Going Green: The Vital Role of Community Colleges in Building a Sustainable Future and Green Workforce. ERIC-Academy for Educational Development. Retrieved from http://eric.ed.gov/?id=ED520114 
Global Insight. (2008). US Metro Economies: current and potential green jobs in the US economy. Retrieved from

http://www.usmayors.org/pressreleases/uploads/greenjobsreport.pdf

Government Accountability Office. (2013). Labor's Green Jobs Efforts Highlight Challenges of Targeted Training Programs for Emerging Industries. Retrieved from http://www.gao.gov/assets/660/655332.pdf

Green Jobs Act. (2007). Green Jobs Act of 2007 (2007; 110th Congress H.R. 2847) GovTrack.us. Retrieved from http://www.govtrack.us/congress/bills/110/hr2847

Kopicki, A., \& Cleary, J. (2009). Preparing the Workforce for a "Green Jobs" Economy. John J. Heldrich Center for Workforce Development. Retrieved from http://www.heldrich.rutgers.edu/sites/default/files/content/Heldrich Center_Green_Jobs_Brief.pdf

Lee, D. (2013). Green jobs grow four times faster than others. Los Angeles Times. Retrieved from http://www.latimes.com/business/money/la-fi-mo-green-jobs20130319,0,2962980.story

Lengnick-Hall, M., Gaunt, P., \& Collison, J. (2003). Employer Incentives for Hiring Individuals with Disabilities Employer Incentives for Hiring Individuals With Disabilities.

Liu, Y., \& Keleher, T. (2009). Green Equity Toolkit, Standards and Strategies for Advancing Race, Gender, and Economic Equity in the Green Economy. Retrieved from http://community-wealth.org/sites/clone.community-wealth.org/files/downloads/report-liukeleher.pdf

Morriss, A. P., Bogart, W. T., Dorchak, A., \& Meiners, R. E. (2009). Green Jobs Myths. SSRN Electronic Journal. doi:10.2139/ssrn. 1358423

National Council for Advanced Manufacturing. (2008). Green Jobs in Manufacturing : A Roadmap for Progressively Greener Solutions through a Sustainable and Green Workforce. Retrieved from http://www.nacfam.org/Portals/0/Sustainable Manufacturing/NACFAMGreenJobs_12.23.08.pdf

Nishii, L. \& Bruyere, S. (2009). Protecting employees with disabilities from discrimination on the job: The role of unit managers. In Workplace policies and practices minimizing disability discrimination: Implications for Psychology. Symposium conducted at the annual convention of the American Psychological Association in Toronto, Canada.

Office of Inspector General - Office of Audit. (2011). Recovery Act: Slow Pace Placing Jobs Jeopardizes Employment Goals of the Green Jobs Program. Retrieved from http://www.oig.dol.gov/public/reports/oa/2011/18-11-004-03-390.pdf 
Schrader, S. von, \& Malzer, V. (2011). Emerging Employment Issues for People with Disabilities: Disability Disclosure Leave as a Reasonable Accommodation Use of Job Applicant Screeners. Report of a Cornell/AAPD Survey. Ithaca, NY: Cornell University Employment and Disability Institute. Retrieved from

http://www.eric.ed.gov/ERICWebPortal/recordDetail?accno=ED537099

Scully-Russ, E. (2012). Are Green Jobs Career Pathways a Path to a 21st-Century Workforce Development System? Adult Learning, 24(1), 6-13. doi:10.1177/1045159512467323

SHRM - Cornell. (2012). Employing People With Disabilities: Practices and Policies Related to Recruiting and Hiring Employees With Disabilities. SHRM-In collaboration with and commissioned by Cornell University ILR School Employment and Disability Institute. Retrieved August 17, 2013, from http://www.shrm.org/Research/SurveyFindings/Articles/Pages/EmployingPeopleWithDisab ilitiesPracticesandPoliciesRelatedtoRecruitingandHiringEmployeesWithDisabilities.aspx

Sommers, D., Warren, Z., \& Watson, A. (2013). BLS green jobs overview. Monthly Labor Review: U.S. Bureau of Labor Statistics. Retrieved from http://www.stats.bls.gov/opub/mlr/2013/01/art1full.pdf

U.S. Department of Commerce. (2010). Measuring the green economy. Retrieved from http://www.esa.doc.gov/sites/default/files/reports/documents/greeneconomyreport_0.pdf

US Department of Labor. (2010a). ETA News Release: US Department of Labor announces \$150 million in "Pathways Out of Poverty" training grants for green jobs [01/13/2010]. Retrieved August 07, 2013, from http://www.dol.gov/opa/media/press/eta/eta20100039.htm

US Department of Labor. (2010b). ETA News Release: US Department of Labor announces $\$ 100$ million in green jobs training grants through Recovery Act [01/06/2010]. Retrieved August 07, 2013, from http://www.dol.gov/opa/media/press/eta/eta20091526.htm

US Department of Labor - ODEP. (2013). Business Strategies that Work : A Framework for Disability Inclusion.

US Department of Labor - ODEP NTAR Leadership Center. (2011a). Green Job: A Resource Guide for Individuals with Disabilities. Retrieved from http://www.dol.gov/odep/pdf/GreenResourceGuide.pdf

US Department of Labor - ODEP NTAR Leadership Center. (2011b). Strategies for Including People with Disabilities in the Green Jobs Talent Pipeline: Roundtable Proceedings. Retrieved from http://www.dol.gov/odep/pdf/GreenProceedings.pdf 


\section{Appendix: Resources}

\section{EARN}

The Employer Assistance and Resource Network (EARN) is a service of the National Employer Technical Assistance Center (NETAC) based at Cornell University's Employment and Disability Institute. EARN's vision is to increase employment and workplace inclusion for people with disabilities by engaging and empowering employers to be leaders in this effort.

http://www.askearn.org/

2. NTAR - National Technical Assistance and Research Center to Promote Leadership for Increasing Employment and Economic Independence of Adults with Disabilities

The NTAR Leadership Center's mission is to increase the employment and economic independence of adults with disabilities by promoting engaged and sustained leadership and partnerships within and among states.

http://www.heldrich.rutgers.edu/projects/all-projects/ntar-leadership-center

\section{United States Department of Labor - Office of Disability Employment Policy}

The Office of Disability Employment Policy (ODEP) provides national leadership by developing and influencing disability employment-related policies and practices affecting an increase in the employment of people with disabilities.

http://www.dol.gov/odep/

4. United States Department of Labor - Good Jobs, Safe Jobs, Green Jobs

The Bureau of Labor Statistics Green Career program produces information on green jobs. The information available for occupations includes: wages, expected job prospects, what workers do on the job, working conditions, and necessary education, training, and credentials.

http://www.dol.gov/dol/green/

5. Workforce ${ }^{3}$ One

Workforce3 One, sponsored by the U.S. Department of Labor/Employment and Training Administration (ETA), is an on-line interactive communications and learning platform designed to build the capacity of the Workforce Investment System. Members include the public workforce system and its strategic partners, such as employers, Federal agencies, communityand faith-based organizations, and educators.

https://www.workforce3one.org/page/home 